\title{
OBITUARY
}

\section{Robin Fletcher}

Robin Anthony Fletcher, who died on 15 January 2016, was born in Godalming on 30 May 1922. He was educated at Marlborough College, as was R. M. Dawkins, who served as Bywater and Sotheby Professor of Byzantine and Modern Greek at Oxford from 1920 to 1939. As Dawkins had done in the First World War, Robin served in the Royal Naval Volunteer Reserve in the Second World War, during which time he commanded a Greek caique in the Eastern Mediterranean. At the end of the war Robin was awarded the Distinguished Service Cross.

In 1946 he went up to Trinity College, Oxford, to read Classics. By the end of his first year, after completing the shortened version of 'Mods' available to ex-servicemen, he had decided to change subject, since he could not face the two years of philosophy that 'Greats' entailed. His first and second choices - history and PPE - were quickly turned down by the College President. When he then suggested Modern Greek, the response was 'How very enterprising'. The die was cast. Robin soon met Constantine Trypanis, who was just then succeeding John Mavrogordato as Bywater and Sotheby Professor, and there can be little doubt that Trypanis had a huge and decisive influence on both his studies and his future academic career.

After two years of study with Trypanis as his sole teacher, he took Finals in the Trinity Term of 1949. Then, in his own words, 'an extraordinary piece of good fortune' came his way. A lectureship in Modern Greek was established at Oxford as a result of the Scarborough Commission, which had recommended an expansion of Slavonic and East European studies (including Modern Greek). Robin applied and was one of two candidates who were under serious consideration, both of whom had taken Finals that year. He tells the story in his autobiography, ${ }^{1}$ with entirely characteristic modesty: 'I am in little doubt that the other competitor, Gareth Morgan, was better equipped than myself but he had not done National Service. For whatever reasons, I was preferred and accepted the offer.'

Robin was one of the last of a generation of British Hellenists whose first encounter with contemporary Greece came during the Second World War; other members included the Byzantine historian Donald Nicol, the translator, philosopher and

1 R. Fletcher, A Favouring Wind: A Passage within and without Academia (2007). Gareth Morgan secured a five-year grant for study in Greece, wrote a path-breaking DPhil thesis on Cretan poetry before 1500, and then pursued an academic career in the USA, becoming Professor of Classics at the University of Texas from 1966 till his death in 1996.

(C) Centre for Byzantine, Ottoman and Modern Greek Studies, University of Birmingham, 2016

DOI: $10.1017 /$ byz.2016.11 
theologian Philip Sherrard, and the anthropologist and historian John Campbell. It was also while serving in the RNVR that Robin met Jinny Cornish (whom he married in 1950) during a posting in her home town of Alexandria.

Robin published little during his academic career. His elegantly written and cogently argued Oxford DPhil thesis, 'The festival of the Annunciation: studies of the festival from early Byzantine texts', approved in 1955, was devoted to a study of the origins of the festival of the Annunciation on 25 March. Having studied evidence from Byzantine hymnography and sermons, as well as from Syriac, Egyptian, Palestinian, Constantinopolitan and Western sources, he argued that the celebration of the Conception of Christ had earlier formed part of the Nativity festival, and he concluded from a study of two hymns by Romanos on Christmas and the Annunciation that the Annunciation hymn was specifically composed for $25 \mathrm{March}$ - an indication that the festival was first established in Constantinople before the middle of the sixth century. In an Appendix he argued that the Akathist hymn was originally composed for the Nativity and not for the Annunciation, and that it was most likely composed by an earlier poet than Romanos. He also confirmed the view that the date of 25 March for the Annunciation was extrapolated from the date of the Nativity, and not vice versa. The thesis was never published, but it led to the publication of a frequently cited article in Byzantinische Zeitschrift on the authorship and dating of three Byzantine hymns and the festivals for which they were composed.

In 1973 Robin contributed a chapter, 'Byron in nineteenth-century Greek literature', to Richard Clogg's edited volume The Struggle for Greek Independence. In this thoroughly researched study of the presence of Byron from Solomos to Palamas, he points to the indifference shown by most Greek intellectuals to Byron's poetry before

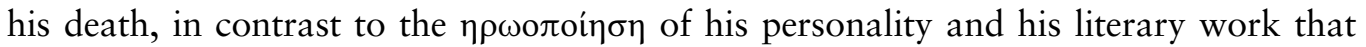
began with Spyridon Trikoupis' funeral oration. Robin suggests the possibility that it was Trikoupis who had introduced Solomos to Byron's work, and that he had discussed with Solomos, and perhaps translated for him, the passages in Canto III of Don Juan to which the poet responded in stanzas 83-5 of the Hymn to Liberty.

For an edited volume entitled Greece in Transition: Essays in the History of Modern Greece 1821-1974 (ed. J. T. A. Koumoulides, 1977), Robin contributed a chapter on 'Cultural and intellectual development 1821-1911'. The scope is broad: education, archaeology, architecture, sculpture, painting, music, literature, theatre, folklore studies, the Great Idea and the struggle for demoticism. At a time when there were few fundamental studies of the sort one would turn to today, it is a remarkable achievement: not a dry encyclopaedic catalogue but an integrated and lively account, in which essential facts are balanced with perceptive judgements.

His major academic publication was his volume Kostes Palamas: A Great Modern Greek Poet, 1859-1943: His Life, his Work, and his Struggle for Demoticism (1984). The book had been completed about seventeen years before, but a series of misadventures and broken promises intervened before it was finally published by the Palamas Institute in Athens. The original plan, negotiated by Constantine Trypanis, 
was for the work to be published by a Greek publisher in Chicago. However, when the book was already in proof, the publisher called off the deal after an argument with Trypanis. With the latter's encouragement and assistance, Robin travelled to Chicago, paid an early morning visit to the publisher's house, and demanded the proofs, which were meekly handed over. That was not the end of it. Robin lent the proofs to Professor George Thomson of Birmingham University, who had translated a major work of Palamas and had a particular interest in the demoticist movement. Some years later, when Robin asked for the return of the proofs in order to make a further attempt to find a publisher, they could not be found. The only surviving text was the bottom carbon copy of the typescript, and it was this that was sent to the Palamas Institute. Someone working for the Institute, who apparently didn't know English or even the Latin alphabet, inked in the letters that were too faint to read, with disastrous consequences that were compounded by equally ignorant typesetters. Fortunately PM happened to be in Athens at the time and was able to correct the proofs on the spot.

Robin's book is a unique and valuable study of Palamas' life and work and on the demoticist struggle in general, topics on which he had given undergraduate lectures over a number of decades. His lectures on demoticism were ultimately what inspired PM to write his book on the history of the Greek language question, published in 2009. The breadth of Robin's interests is further attested by his research on the textual transmission of Digenis Akritis and the life and work of Adamantios Korais, though neither project resulted in publication, except for a critical bibliography of 'The epic of Digenis Akritas and the Akritic Songs' published in 1977.

Robin's role as Lecturer in Modern Greek at Oxford (1949-80) was just one of his several identities. A member of the British hockey team in the Helsinki Olympics of 1952, at which they won a bronze medal, he managed the British team at the 1964 Tokyo Olympics and served as President of the Hockey Association from 1973 to 1983, in which year he was awarded an OBE for his services to hockey. For most of his teaching career at Oxford, between 1951 and 1974, he also served as Domestic Bursar of Trinity College - a post that would nowadays be considered to be full-time. He also did valuable service to the university on various committees and was Senior Proctor in 1966-7. He served as Treasurer for the Congress of Byzantine Studies which was held in Oxford in 1966.

Robin was a genial and entertaining undergraduate tutor and graduate supervisor. He belonged to the generation of Oxford dons who served sherry and stiff martinis to pupils whose tutorials conveniently took place shortly before lunch or dinner, and he and Jinny were immensely generous in their invitations to his students to attend their regular Wednesday lunches cooked and served by Jinny in their flat above Trinity College gatehouse. A man of great gentleness, charm and modesty, he was famous for his constant good humour and for periodically breaking into slightly embarrassed highpitched giggles, as well as for puffing at his pipe while teaching. He smoked during tutorials and, though he was obliged by regulations to extinguish his pipe during lectures, he would puff at it all the same. PM was the fortunate recipient of Robin's set 
of Palamas' complete works in 1980, and the volumes are still redolent of Robin's pipe smoke to this day. After his elevation to the wardenship of Rhodes House in 1980 and his and Jinny's consequent move from their Trinity flat to the warden's palatial residence, he would be amused by the dilemmas caused by the multiplicity of reception rooms and by the necessity for Jinny to ring a bell to announce lunch or dinner to those who were assembled in whichever distant living room had been chosen for pre-prandial drinks.

Robin left a rich legacy of students who went on to become distinguished Hellenists. Meg Alexiou has written: 'It is odd, but not incongruous, that both Robin Fletcher and Stavros Papastavrou, in their very different ways, inspired so many of our own and younger generations of Byzantinists and neohellenists.' Among those whom Robin taught, as undergraduates or graduate students or both, are those mentioned in the following paragraphs (in alphabetical order).

Rosemary Bancroft (later Bancroft-Marcus) published in 2013 the first edition of the complete works of the Cretan Renaissance playwright Georgios Chortatsis, in the original and in English translation, an edition that had its origins in the 1978 DPhil thesis on Chortatsis that she wrote under Robin's supervision. Margaret Carroll taught at two Australian universities; she is the author of A Contemporary Greek Source for the Siege of Constantinople 1453: The Sphrantzes Chronicle (1985) and the co-editor (with Stathis Gauntlett) of the anthology Images of the Aegean (1980) dedicated to Robin. David Connolly became Professor of Translation Studies at the University of Thessaloniki and is one of the foremost translators of Greek literature into English, including volumes of poetry and essays by Odysseus Elytis, Nikos Engonopoulos, Nikiforos Vrettakos, Kiki Dimoula, Yannis Kondos, Yoryis Yatromanolakis, Rhea Galanaki, Haris Vlavianos and Alexis Stamatis, and some of the detective novels of Petros Markaris.

Mark Quentin Davies, who taught English in the USA and subsequently at the University of Melbourne, is the author of Blake's Designs for Paradise Lost (1980) and more recently the translator of Konstantinos Theotokis' Slaves in their Chains, which he first read with Robin in the early 1960s. Lynda Garland taught for many years at the University of New England, Armidale and is a past President of the Australian Association for Byzantine Studies. Her numerous publications cover many aspects of Byzantine studies, including social and political history, issues of gender, and the romance genre. Stathis Gauntlett was the first person to write a doctoral dissertation on

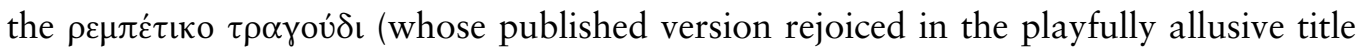
Rebetika carmina Graeciae recentioris) and went on to be Professor of Modern Greek at the University of Melbourne, and subsequently at LaTrobe University. David Holton became Professor of Modern Greek at Cambridge, Elizabeth Jeffreys became Bywater and Sotheby Professor at Oxford, and Peter Mackridge (DPhil 1974) became Robin's successor as Lecturer in Modern Greek (and later Professor of Modern Greek) at Oxford. Christopher Robinson taught French and Modern Greek literature for many years at Christ Church, Oxford, and published a useful book on Cavafy's poetry as well 
as articles on Psycharis, Elytis, Ritsos, Greek Surrealism, Kostas Tachtsis, Yorgos Ioannou, and twentieth-century Greek women's poetry.

On Robin's retirement from Rhodes House in 1989, he and Jinny retired to the Orkneys. Of their two sons, Clive died of multiple sclerosis, while Denys moved to Stromness to be close to them in their old age. Jinny died in 2010 aged 88.

Robin was a kind and thoughtful man. He is remembered with immense affection by his students.

David Holton

Peter Mackridge 